\title{
On Fiscal Policy and Budget Deficits
}

\author{
Philip Arestis $^{*}$ and Malcolm Sawyer ${ }^{\circ}$
}

\begin{abstract}
A major argument used against the use of fiscal policy comes from the view that there are automatic forces within an economic system to ensure high levels of demand. This paper argues that the case for fiscal policy in general rests on the proposition that there are no such market forces that ensure high levels of demand. There is, thus, a need for macroeconomic policy to perform this task. The argument against fiscal policy to the effect that it does not raise the level of economic activity, does not apply when this view of fiscal policy is adopted.

JEL classification: E62
\end{abstract}

\section{The misunderstood purpose of budget deficits}

The case for the use of fiscal policy and hence for governments to operate with an unbalanced budget (whether in surplus or deficit) arises from the simple Keynesian proposition that the level of private aggregate demand does not generally correspond to a high level of economic activity (Kalecki 1939, Keynes 1936). Further, there is no automatic market mechanism to bring aggregate demand to an appropriate level compatible with the desired level of economic activity. The notion that the budget should always be in balance (or even on average in balance) is rejected on the grounds that a balanced budget is generally not compatible with the achievement of high levels of aggregate demand.

A major argument used against the use of fiscal policy is that there are adjustment mechanisms which do ensure such high levels of demand. In this regard, the major theoret-

* University of Cambridge, Levy Economics Institute.

- University of Leeds.

Correspondence address:

Prof. Philip Arestis, Cambridge Centre for Economic and Public Policy, Department of Land Economy, University of Cambridge, i9 Silver Street, Cambridge CB3 9 EP, UK, e-mail:pa267@cam.ac.uk

Received 03 Apr 2004, accepted 24 Jun 2004

(C) Intervention. Journal of Economics, Vol. 1 (2004), No. 2, p. 61-74 
ical argument has been the operation of the real balance effect (Pigou effect): low demand generates falling prices and rising real value of the money stock and wealth, which stimulates demand. The level of aggregate demand is (eventually) brought into line with the supply-side equilibrium. But it is well known (at least since Kalecki 1944a) that the real balance effect relies on "external" money with net worth to the private sector and to the stock of money remaining unchanged in the face of price changes. In a world of largely bank credit money, the amount of "external " money is relatively small: for example in the UK the ratio of Mo to GDP is less than four per cent; a price fall of Io per cent would increase real value of Mo by the equivalent of 0.4 per cent. With a wealth effect on consumption of the order of 0.02 to 0.05 (OECD 2000: 192), aggregate demand would change by the order of 0.0 I per cent (for a decline of ten per cent in the price level). As prices fall, the demand for Mo would fall and hence the stock of Mo would also fall. The empirical relevance of the real balance effect has long been doubted (though it continues to make an appearance in many macroeconomic models, notably those of a new Keynesian form). Further, there are good reasons to doubt the theoretical relevance as well. When money is treated as endogenous money, then the stock of money is determined by the demand for money, and money does not constitute net worth. Hence the theoretical reasons for the stock of money influencing the level of aggregate demand disappear.

Another adjustment mechanism, which has recently been more widely used in analysis and to some degree in policy, and which has rather more plausibility than the real balance effect, arises from the operation of interest rate policy by the Central Bank. It should be noted that this is not a market adjustment mechanism, but rather arises from the operation of monetary policy. This could occur if the Central Bank adopted some form of "Taylor's rule" under which the setting of the key interest rate depends on the "equilibrium « rate of interest, deviation of inflation from target and deviation of output from trend level (Taylor 1993). The "equilibrium « rate of interest is then seen to be that which brings aggregate demand in line with available supply (and a constant rate of inflation). However, there has to be considerable doubt as to whether feasible variations in the rate of interest are sufficient to equate savings and investment at a high level of economic activity. There are constraints on the extent to which interest rates can be varied (whether for reasons akin to a liquidity trap in operation which prevent the reduction of interest rates below a particular level or for foreign exchange considerations), and there are doubts relating to the potency of interest rates to influence aggregate demand (Arestis/ Sawyer 2004a).

These considerations are significant in two respects. First, they suggest that there are no automatic market mechanisms, which will bring aggregate demand for a high level, and hence there is a need for macroeconomic policy to do so. Second, the rate of interest is a possible policy instrument, but doubt can be cast on its effectiveness in securing high levels of demand. The change in the rate of interest is an act of government (albeit in the form of the actions of the Central Bank), and that raises the question of the alternative policy instrument, namely fiscal policy. In effect we argue that fiscal policy is a more potent tool than monetary policy (Arestis/Sawyer 2004b). 
This paper argues that, when fiscal policy is approached from the perspective of "functional finance", that the arguments, which have been raised against fiscal policy and budget deficits, do not hold. The "functional finance " approach ${ }^{\mathrm{I}}$ is that the purpose of fiscal policy is seen as being to secure the desired level of economic activity, rather than to achieve a particular budget position (e.g. to balance the budget whether on an annual basis or over the course of the business cycle). ${ }^{2}$ A budget deficit is used to boost aggregate demand when it would otherwise be insufficient to reach that desired level of economic activity (and also a surplus is run when aggregate demand would otherwise be too high). From that perspective, the role of fiscal policy should be evaluated against a background of insufficient aggregate demand, since the case for fiscal policy is the case to address insufficient aggregate demand. Basing an analysis of the effects of budget deficits on economic activity under the assumption that aggregate demand is always sufficient (i.e. assuming something akin to Say's Law) is then quite inappropriate: if aggregate demand was sufficient, there would be no requirement from a "functional finance" perspective for a budget deficit. This paper puts forward the view that the argument which have been deployed against budget deficits to the effect that they do not raise the level of economic activity do not apply when this Keynesian perspective is adopted.

\section{Funding the budget deficit}

The starting point for considering the funding of a budget deficit is the well-known equation of injections equals leakages in terms of the circular flow of income, namely:

$$
G+I+X=T+S+Q
$$

I The term "functional finance» indicates one source of this approach, namely Lerner (1943), who introduced that term. In a similar vein, Kalecki (1944a) argued that sustained full employment "must be based either on a long-run budget deficit policy or on the redistribution of income» (p. 135). Kalecki based his argument on the assumption that there would be a tendency for the level of aggregate demand to fall short of what was required for full employment. Then there was a need for either a budget deficit to mop up with the difference between full employment savings and investment, or for full employment savings to be reduced through a redistribution of income (from rich to poor). He also argued that "although it has been repeatedly stated in recent discussion that the budget deficit always finances itself - that is to say, its rise always causes such an increase in incomes and changes in their distribution that there accrue just enough savings to finance it - the matter is still frequently misunderstood" (Kalecki 1944b).

2 There has been some revival of interest in "functional finance« (e.g. Nell/Forstater 2003). The purpose of this paper is not to consider that revival of interest, but rather to evaluate the arguments against the use of fiscal policy and budget deficits from a "functional finance" perspective. 
where $G$ is government expenditure, $I$ investment, $X$ exports, $T$ tax revenue, $S$ savings and $Q$ imports.

From this perspective, the budget deficit is to be used to mop up "excess" private savings (over investment), and the counterpart budget surplus used when investment expenditure exceeds savings (at the desired level of economic activity). It follows, though, that a budget deficit is not required when there is a high level of private aggregate demand such that investment equals savings at a high level of economic activity (and a surplus would be required when investment exceeds savings at the desired level of economic activity). This can be expressed as that the government should set tax and expenditure such that the resulting budget deficit is given by :

$$
G-T=S\left(Y_{f}\right)-I\left(Y_{f}\right)+Q\left(Y_{f}\right)-X(W Y)
$$

where $Y_{f}$ is the intended level of income (which may be thought of as equivalent to full employment or to some supply side constraint) and $W Y$ is world income (which is taken as given for the purposes of this equation). A tendency for savings to run ahead of investment leads to the view that a budget deficit is required (in the absence of any tendency for balance of trade surplus). But it is a short-fall of investment over savings that creates the requirement for a budget deficit: in the absence of any such short-fall (in ex ante terms) there is no need for a budget deficit. The analysis of budget deficits should then be undertaken in a context which at least allows for the emergence of an excess of (ex ante) savings over (ex ante) investment corresponding to high levels of income. In the absence of any such excess, the "functional finance" view would not see any cause for a budget deficit.

The case for fiscal policy rests on the proposition that the equality between ex ante savings and ex ante investment at full employment income cannot be assured (or indeed at any target level of income). ${ }^{3}$ If there were some automatic tendency, as expressed in, for example, Say's Law, for that equality to be assured, then any case for fiscal policy in the form of unbalanced budgets would disappear. Further, if the relevant rate of interest can be manipulated through monetary policy in such a way as to ensure this equality, then again there would be little room for fiscal policy.

The general presumption of Keynesians and others has been that there is likely to be a deficiency of ex ante investment relative to ex ante savings, rather than the reverse. This does not rule out that there will be occasions (as in the late I99os in the UK and the USA with conditions of low unemployment) when investment runs ahead of savings. In the former case, a budget deficit is required to mop up the excess savings, while in the latter case a budget surplus results.

The government can then always fund a budget deficit and will do so with a mixture of sale of bonds and issue of money. The mix between bonds and money generally

3 This discussion is cast in terms of a closed economy: adjustments to account for an open economy can be readily made without undermining the basic approach pursued here. 
rests on the willingness of the public to hold bonds and money as part of their wealth portfolio (and this may be influenced by the rate of return on bonds). As the holding of government issued money is a relative small proportion of wealth, in general bonds will fund the bulk of any budget deficit. Most governments are not able to directly "print money", but rather must secure (through taxation or borrowing) the money to initially finance their spending. After the spending has occurred, central banks, through open market operations and the like, can then put high-powered money into the economic system.

A frequent objection to the use of fiscal policy is the argument that the government may not be able to fund budget deficits, and hence attempts to stimulate the economy through fiscal policy and budget deficits will be frustrated. This argument is clearly wrong, since budget deficits are required because there is an excess of (ex ante) savings over investment (at the desired level of income). If a budget deficit cannot be funded, that is because there is an absence of that excess of savings over investment, in which case a budget deficit would not be required. When there is an excess of savings over investment, then a budget deficit is required to absorb the excess savings, but that, of course, is precisely the situation in which the budget deficit can be funded.

Fiscal policy is often viewed in terms of the determination of government expenditure and taxation as undertaken without specific regard to the state of private aggregate demand. The "crowding out" argument after all assumes that there is something to be crowded out. That approach to fiscal policy suggests either that fiscal policy has no effect on the level of economic activity (since there is crowding out), or that there is a positive link between government expenditure (budget deficit) and the level of economic activity. The investigation of fiscal policy through the means of simulation of macroeconometric models is concerned (usually) with the question of what happens if government expenditure is increased, other things being equal. The results of such simulations, generally, suggest that an increase in government expenditure does have a positive effect on the level of economic activity (Arestis/Sawyer 2003). Indeed in the context in which these simulations are undertaken, it is somewhat surprising that positive results are obtained, since such macroeconometric models generally build in a variety of ways by which there would be crowding out - the most notable one being that imposition of some form of supply-side equilibrium, and an adjustment process by which the economy moves to that supply-side equilibrium.

The effects of fiscal policy (especially when that takes the form of a budget deficit) start from the position that budget deficits are applied when there would otherwise be a deficiency of aggregate demand (below that required for the target level of economic activity), and conversely budget surpluses applied when there would otherwise be an excess of aggregate demand. This is not to say that fiscal policy has been always (or even usually) applied in this manner. But it is to argue that fiscal policy and its effects should be evaluated against this background. The evaluation of fiscal policy should not start from the presumption that there would otherwise be adequate effective demand, in that all would agree that in the context of adequate private effective demand there is no requirement 
for budget deficits. There have been three distinct sets of arguments to the effect that fiscal policy will be ineffective, under the general heading of "crowding out", and these are now considered in turn.

\section{Sustainability of budget deficits}

The use by government of budget deficits to sustain aggregate demand raises the issue of the sustainability of continuing budget deficits. A frequently heard argument against the use of budget deficits is that they cannot be sustained. Here we argue that when budget deficits are approached from a "functional finance " perspective, then budget deficits are indeed sustainable.

The growth of government debt $B$ is given by $d B / d t=D+r B$, where $D$ is the primary budget deficit and $r$ the rate of interest on government debt (as some deficit is money-funded, this rate of interest would be somewhat below the rate of interest on government bonds). The rate of change of the debt to income ratio is then given by $d(B / Y) / d t=D / B+r-g=$ $d / b+r-g$, where $g$ is the rate of growth of income $Y, d=D / Y$, and $b=B / Y$. For a given primary budget deficit (relative to income), the debt to income ratio would stabilise at $b=d /(g-r)$, which requires $g>r$. Note that in this formula, $g$ and $r$ can either be both in real terms or both in nominal terms, and that the relevant interest rate is the post-tax rate on government bonds. ${ }^{4}$ As Lerner (1943), Domar (1944) and others established, a permanent primary budget deficit could be sustainable, provided that the growth rate exceeds the interest rate.

However, it is the total budget deficit including interest payments which is relevant in the sense that it is that type of budget deficit which "mops up « excess private savings. For a given total budget deficit (relative to income), the debt to income ratio stabilises at $b=(d+b r) / g$. In that context, the budget deficit is always sustainable in the sense that the debt to income ratio stabilises rather than continues to grow indefinitely, provided that nominal growth is positive. It can be noted that the primary budget position may be in surplus though the total budget is in deficit in light of the interest payments. Further, when there is inflation, the budget deficit in nominal terms overstates the deficit in real terms to the extent of the decline in the value of the government debt.5 Whenever the relevant budget deficit is the overall one, there is not (in the absence of negative nominal growth) a sustainability issue for the overall deficit.

4 Assuming that the budget deficit is entirely bond-financed: to the extent to which the deficit is money-financed, the average rate of interest on government debt will be lower.

5 In the current context of the European Stability and Growth Pact, the (on average) balanced budget requirement, the 60 per cent debt to income ratio, and an inflation target of two per cent imply that the primary budget is in substantial surplus (on average), and that in real terms the total budget is in surplus to around I.2 per cent (since there is a two per cent decline in the real value of the outstanding debt). 
The argument is also put that if the government debt to GDP ratio rises, then the private sector becomes satiated with public debt and is unwilling to absorb more. This, it is argued, would also lead to rising interest rate of government bonds, as the government continues to borrow and has to persuade the private sector to accept the increasing debt. However, consider the implications of a private sector satiated with public debt - it would imply that private savings and private investment are in balance, and the private sector does not have savings, which it wishes to lend to the public sector. But if (ex ante) savings and investment are in line with each other, there is no insufficiency of aggregate demand, and no requirement for a budget deficit.

\section{Fiscal deficits and the supply side}

It is often asserted that any attempt by government to stimulate the economy through fiscal policy will be "crowded out", leaving the level of economic activity unchanged, and this assertion arises from a combination of the notion of a supply-side equilibrium (such as the "natural rate of unemployment" or the non-accelerating inflation rate of unemployment, the NAIRU), and that the level of aggregate demand would adjust to be consistent with that supply-side equilibrium. In the context of an exogenous money supply, this came through the assertion of a "real balance « effect, with changes in the price level generating changes in the real value of the stock of money, thereby generating changes in the level of aggregate demand. In the context of endogenous money, it would come through the adjustment of the interest rate by the Central Bank. Monetary policy can guide aggregate demand to match supply, provided that interest rates are effective in influencing the level of demand, and provided that the Central Bank's calculation of the "equilibrium rate" of interest is accurate. As has been argued above, fiscal policy has an effect on the level of aggregate demand, and "crowding out « only occurs if it is assumed that the supply-side equilibrium must be attained (in order to ensure a constant rate of inflation) and that the level of aggregate demand would anyway be equivalent to the supply-side equilibrium. In the absence of some powerful automatic market forces or a potent monetary policy, which can ensure that the level of aggregate demand moves quickly to be consistent with the supply-side equilibrium, then fiscal policy has a clear role to play.

The path of aggregate demand does itself influence the supply-side potential of the economy (and hence any supply-side equilibrium which may be calculated). The size and distribution of the capital stock is a determinant of the productive capacity of the economy, and a larger capital stock would be associated with the supply-side equilibrium involving a higher level of output and employment. The level of aggregate demand (including the change in economic activity and profitability) has an impact on investment expenditure, and thereby on the size of the capital stock. The supply-side equilibrium may form an inflation barrier at any point in time, but it is not to be seen as something immutable and unaffected by the level of aggregate demand. 
If the representation of the economy (economic model) is such that there are selfcontained subsets of equations from which equilibrium solutions can be derived, then it is possible to speak of equilibrium positions relating to each of the sub-set of equations. In particular, if there is a sub-set of equations, which can be viewed as relating to the supply-side of the economy, then it is possible to speak of a supply-side equilibrium; and similarly for a demand-side equilibrium. The "natural rate of unemployment" and the NAIRU appear to fall into the category of supply-side equilibrium positions. In this context, the supply-side equilibrium seems to place a constraint on the level of output or employment (more generally the level of economic activity). In the present context, the supplyside equilibrium would appear to limit any role for fiscal policy (acting on the demand side of the economy) in that economic activity cannot be raised above the supply-side equilibrium for any length of time. However, this notion of supply-side equilibrium and the dichotomy (separation) between the supply-side and demand-side of the economy (which sometimes corresponds to the separation between the real side and the monetary side of the economy as in the classical dichotomy) raises three issues.

First, what, if any, are the mechanisms on the supply-side of the economy, which take the economy to the supply-side equilibrium position? Second, are there mechanisms which bring a compatibility between the supply-side and the demand-side of the economy? Third, are there interactions between the supply-side and the demand-side of the economy which are generally overlooked? We now look at these issues in turn.

On the first issue, it could be said little attention has been given to this. However, when the supply side is viewed as akin to a competitive (labour) market (with the "natural rate of unemployment" as the supply-side equilibrium), then an adjustment mechanism appears to be changes in real wages. In the expectations-augmented Phillips curve, changes in real wages (expressed in terms of changes in nominal wages minus expected inflation) are linked with unemployment as a (negative) proxy for excess demand for labour. Real wages continue to adjust until the "natural rate of unemployment" is attained. This approach implicitly assumes that the cause of unemployment (and indeed over employment) arises from real wages differing from the equilibrium level. No attention is given to the level of aggregate demand, and implicitly it is assumed that the level of aggregate demand underpins the level of employment as set by the level of real wages. In the more general NAIRU approach, based on imperfect competition and wage bargaining (e.g. Layard et al. 199I), there is no obvious supply-side adjustment mechanism. Wages and prices change in response to the level of demand, but there is no mechanism at work which guides the level of real wages to its equilibrium level. ${ }^{6}$ The adjustment in this NAIRU approach comes from the demand side alone.

Turning now to the second and third issues, we may comment first on the relationship between the demand side and the supply side of the economy, in the sense of changes on one side having a long-lasting impact on the other side (rather than just an adjustment process), which is often seen as non-existent. However, there are reasons for thinking that

6 See Sawyer (1999) for further discussion. 
is not the case. The most cited example comes under the label of hysteresis effects in the labour market: periods of low demand and high levels of unemployment are viewed as having "scarring " effects on the work force and the effective supply of labour. Without dismissing such effects, in the context of the present paper a more significant effect may come through the effects of aggregate demand on investment, and of investment on productive capacity (and hence the supply side of the economy). This relates to the third issue raised above. Fiscal policy boosts aggregate demand, and thereby has a stimulating impact on investment, which raises the future productive capacity of the economy. Further, some contributors have viewed public sector investment as a form of expenditure, which can be varied according to the state of private demand, ${ }^{7}$ and to the extent to which the budget deficit permits additional public investment there can also be a boost to future productive capacity. ${ }^{8}$ The growth rate of the economy may thereby be favourable enhanced by fiscal policy.

\section{Ricardian equivalence and the budget constraint}

The "Ricardian equivalence" proposition is that the future prospects of taxation to pay for a bond-financed budget deficit reduces consumer expenditure (and increases savings), which may exactly offset the boost to expenditure arising from the budget deficit. The overall level of savings (public savings plus private savings) remains unchanged.

The Ricardian equivalence proposition has been derived in the context of full employment (or at least a level of income set on the supply side of the economy) and the implicit assumption that private sector aggregate demand will underpin that level of income. Thus, the Ricardian equivalence proposition is essentially irrelevant in the context of "functional finance«. The Ricardian equivalence proposition relates to the question of what happens if a budget deficit were introduced into a situation where ex ante investment and savings were equal at full employment (or equivalent). "Functional finance« is concerned with

7 Keynes (1980) argued for public investment to be set such that Private Investment + Public Investment $=$ Savings, and hence that the budget deficit appeared to finance public investment. Keynes (op. cit.) also advocated that "in peace-time budgets through the Chancellor making a forecast of capital expenditure under all heads, and comparing this with prospective savings, so as to show that the general prospective set-up is reasonably in accordance with the requirement of equilibrium. The capital budget will be a necessary ingredient in this exposition of the prospects of investment under all heads. If, as may be the case, something like two-thirds or three-quarters of total investment will be under public or semi-public auspices, the amount of capital expenditure contemplated by the authorities will be the essential balancing factor. This is a very major change in the presentation of our affairs and one, which I greatly hope we shall adopt. It has nothing whatever to do with deficit financing " (p. 352).

8 This would depend on the nature of the investment, e.g. investment in roads or in defence equipment, and the productivity of that investment. 
the policy recommendation of introducing a budget deficit into a situation where there is a difference between ex ante savings and ex ante investment (usually an excess of savings over investment) at full employment.

The "Ricardian equivalence" proposition clearly indicates that the level of aggregate demand is invariant to the budget deficit position. But it does not indicate what that level of private demand will be, though there is perhaps the presumption that some form of Say's Law will operate, and that aggregate demand will be sufficient to underpin full employment. However, there is no particular reason for this level of aggregate demand to correspond to any supply-side equilibrium. Specifically, in the event of a shift in the supplyside equilibrium, there is no assurance that there will be a corresponding shift in the level of private demand. Estimates of the supply-side equilibrium NAIRU vary over time and across country. But there would be little reason to think that private aggregate demand would be shifting to correspond to the shifting NAIRU.

There is also the approach by Barro (1974) which could be seen to revive interest in the Ricardian equivalence proposition under the heading of

"are government bonds net wealth?" We have dealt with this approach recently (Arestis/Sawyer 2003), and found it wanting on several grounds. Interestingly enough, and in a later contribution, Barro (1989) lists five "major theoretical objections that have been raised against the Ricardian conclusions. The first is that people do not live forever, and hence do not care about taxes that are levied after their death. The second is that private capital markets are imperfect with the typical person's real discount rate exceeding that of the government. The third is that future taxes and incomes are uncertain. The fourth is that taxes are not lump sum, since they depend typically on income, spending, wealth and so on. The fifth is that the Ricardian result hinges on full employment« (p. 40).

Further objections may be added to the list: less than perfect foresight; partial liquidity constraints; a non-altruistic desire to pass some of the current fiscal burden to future generations (Mankiw/Summers 1984, Blanchard 1985). There may also be significant distributional effects, assumed to be negligible by the proponents. Furthermore, empirical work on Ricardian Equivalence produces evidence that is mixed at best (Cunningham/Vilasuso 1994-95). A more recent study reaches even more negative conclusions:

"There is little evidence of direct crowding out or crowding out through interest rates and the exchange rate. Nor does full Ricardian equivalence or a significant partial Ricardian offset get much support from the evidence« (Hemming et al. 2002: 36).

When fiscal policy is approached in "functional finance» terms, which is a budget deficit run by the government because there is a difference between savings and investment at the desired income level, then the Ricardian equivalence approach is also scarcely relevant. In the absence of a budget deficit, the excess of savings over investment cannot occur (and the discrepancy is dealt with through a fall in income reducing savings until brought into line with income). 


\section{The irrelevance of the current account versus capital account distinction}

The Stability and Growth Pact of the EU requires national governments to (at least) balance their budgets over the economic cycle and constrain budget deficits to a maximum of three per cent of GDP (though these have been observed in the breach over the past three years). The "functional finance" arguments which we have advanced form an implicit critique of that Pact. An alternative fiscal policy rule which has been advocated to replace the Stability and Growth Pact and forms the basis of the fiscal rules of the UK government separates current expenditure and capital expenditure. This "golden rule« of fiscal policy has been described in the following terms:

"Over the economic cycle the government will borrow only to invest and not to fund current expenditure « and "public debt as a proportion of national income will be held over the economic cycle at a stable and prudent level« (Treasury 1997: I).

The appeal of the "golden rule" arises from the notion that borrowing is not undertaken for current expenditure but is undertaken for capital expenditure, perhaps under the misapprehension that capital expenditure by government generates future income (for government), which can be used to pay off the borrowing. But capital expenditure by general government (which is here distinguished from capital expenditure by public corporations) does not yield any direct future "profit" to the government. Some forms of capital expenditure (e.g. roads) may aid national prosperity and thereby raise national income and tax revenue. But that is also true of many forms of current expenditure, most notably that on education and health services.

The distinction in the government accounts between current expenditure and capital expenditure is one between expenditure on goods and services, which are "consumed" within the year, and expenditure on goods, which are long lasting. It is often relatively easy to convert a current expenditure into capital expenditure and vice versa. Instead of purchasing an asset, which would count as capital expenditure, it may often be possible to hire the services of a corresponding asset, which would count as current expenditure. There are many ways in which expenditure can be shifted from the current head to the capital head (or vice versa) without any significant impact on the activity being undertaken. Instead of purchasing a capital asset from which a stream of future services will be derived, the asset can be leased or rented. Expenditure on pensions could be capitalised by the device of the government purchasing a financial »instrument " on the day of an individual's retirement, which would yield the required pension for an individual as an annuity, and thereby to convert (future) current expenditure into present capital expenditure. In a similar manner, much of social security (e.g. child benefits) could be converted into capital expenditure (for example a lump-sum paid to parents on birth of child rather than being paid over a number of years).

There is a different, and we would argue more appropriate, way of drawing the distinction between current and capital expenditure. The distinction which we would make is 
between those forms of expenditure the effects of which are short-lived, and those forms of expenditure whose effects are long-lasting. Thus, expenditure on education would (nearly) all be regarded as long-lasting in that the education provided has an impact on the individual receiving the education for many years after. Then virtually all education expenditure would be treated as capital expenditure since the benefits of education now will accrue over many years into the future.

In pursuing this distinction, it may be useful to draw on the notion of tangible and intangible investments: in business terms the former involves the acquisition of physical assets and stock which have a monetary value, whereas the latter involves non-physical assets such as goodwill, patents etc. The overall value of a business depends on both its tangible and intangible assets. For the government, schools, hospitals, roads etc. constitute tangible assets, whilst the provision of education and health services creates intangible assets. But it is, of course, the case that most of those tangible assets are owned by the government, although they do not generally yield a direct monetary return, whilst the intangible assets are not owned by the government. Insofar as it could be said that these intangible assets are owned by anyone and who received the benefits from those assets, it would be the person who received the education, the health service etc. However, these intangible assets may yield the government an indirect monetary return through enhanced levels of taxation in so far as education and health promote faster economic growth.

The present notion of capital public expenditure relates to the acquisition of capital assets by the government, whether or not these capital assets yield income directly to the government (indeed most of the assets do not, since they do not produce marketable output). The notion proposed above relates to the creation of capital assets through public expenditure, no matter who owns those assets and no matter whether they are tangible or intangible. Thus public expenditure on education creates "human capital for the individual receiving the education from which a variety of benefits for that individual and others flow. Some of these benefits may accrue to the government in the form of higher tax revenue, and the government has a higher and better quality human capital stock on which to draw.

Capital expenditure from the perspective of adding to economic growth and future taxation may be quite different from what should be seen as capital expenditure from the perspective of the acquisition by the government of capital assets. Under the former perspective, much of the expenditure on education, training, research and development, some parts of health care, road construction would be treated as capital expenditure. Under the latter perspective, the purchase of military hardware, buildings and roads would be the main items of capital expenditure.

The focus of the "functional finance " approach is that budget deficits should be used to stimulate aggregate demand, and from that perspective a euro spent on capital expenditure is the same as a euro spent on current expenditure. The "functional finance " approach is concerned over the level of public expenditure relative to the level of taxation: it is not particularly concerned over the allocation of public expenditure between different areas. 
The advocates of "functional finance « would also advocate that public expenditure is spent wisely. But there is no reason to think that a level of capital expenditure equal (on average) to the budget deficit is the appropriate level of public capital expenditure.

\section{Conclusions}

A major argument, which has been used against fiscal policy, is the view that there are automatic forces within an economic system which ensure high levels of demand. We have argued in this paper that the case for fiscal policy in general rests on the proposition that there are no such automatic (market) forces which ensure high levels of demand. The notion that the budget should always be balanced should be rejected on the grounds that such a budget is generally not compatible with the achievement of high levels of aggregate demand. There are no automatic market mechanisms which will bring aggregate demand for a high level, and hence there is a need for macroeconomic policy to do so. The rate of interest is a possible policy instrument, but doubt can be cast on its effectiveness in securing high levels of demand. This raises the question of the alternative policy instrument, namely fiscal policy.

This paper is firmly based on the view that the role of fiscal policy is to influence the level of aggregate demand, and specifically to raise aggregate demand when it would otherwise be too low. The argument against fiscal policy to the effect that it does not raise the level of economic activity does not apply when this view of fiscal policy is adopted.

\section{References}

Arestis, P./Sawyer, M. (2003): Reinventing Fiscal Policy, in: Journal of Post Keynesian Economics, Vol. 26, No. I, pp. 3-25

Arestis, P./Sawyer, M. (2004a): Can Monetary Policy Affect the Real Economy?, in: European Journal of Finance, Vol. 3, No. 3, pp. 9-32

Arestis, P./Sawyer, M. (2004b): On the Effectiveness of Monetary Policy and of Fiscal policy, in: Review of Social Economy (forthcoming)

Barro, R.J. (I974): Are Government Bonds Net Wealth?, in: Journal of Political Economy, Vol. 82, No. 6, pp. I095-III7

Barro, R. J. (1989): The Ricardian Approach to Budget Deficits, in: Journal of Economic Perspectives, Vol. 3, No.2, pp. 37-54

Blanchard, O. J. (1985): Debt, Deficits and Finite Horizons, in: Journal of Political Economy, Vol. 93, No. 2, pp. 223-247

Cunningham, S.R./Vilasuso, J. (1994-95): Is Keynesian Demand Management Policy still Viable?, in: Journal of Post Keynesian Economics, Vol. I7, No. 2, pp. 23I-248

Domar, E. D. (1944): The `Burden of the Debt and the National Income, in: American Economic Review, Vol. 34, No. 4, pp. 798-827 
Hemming, R./Kell, M./Mahfouz, S. (2002): The Effectiveness of Fiscal Policy in Stimulating Economic Activity: A Review of the Literature, IMF Working Paper, No. 02/208, Washington D.C.: International Monetary Fund

Kalecki, M. (1939): Essays in the Theory of Economic Fluctuations, New York: Russell \& Russell Kalecki, M. (I944a): Professor Pigou on 'The Classical Stationary State: A Comment, in: Economic Journal, Vol. 54, No. I, pp. I3I-I32

Kalecki, M. (I944b): `Three ways to Full Employment،, in: Oxford University Institute of Statistics (ed.), The Economics of Full Employment, Oxford: Blackwell

Keynes, J. M. (1936): The General Theory of Employment, Interest and Money, London: Macmillan

Keynes, J. M. (1980): Activities 1940-1946 Shaping the Post-War World: Employment and Commodities, Collected Writings, Vol. 27, London: Macmillan

Layard, R./Nickell, S./Jackman, R. (I99I): Unemployment: Macroeconomic Performance and the Labour Market, Oxford: Oxford University Press

Lerner, A. (1943): Functional Finance and the Federal Debt, in: Social Research, Vol. Io, No. I, pp. 38-5I; reprinted in: Mueller, M. G. (ed.), Readings in Macroeconomics, New York: Holt, Rinehart and Winston, 1966, pp. 353-360 (page numbers refer to the reprint)

Mankiw, G. N./Summers, L. H. (1984): Do Long-term Interest Rates Overreact to Short-term Interest Rates?, NBER Working Paper, No. 1345, Cambridge Massachusetts: National Bureau of Economic Research

Nell, E. J./Forstater, M. (2003): Reinventing Functional Finance, Cheltenham, U. K.: Edward Elgar

OECD (2000): Economic Outlook 68, Paris: OECD

Taylor, J. (1993): Discretion versus Policy Rules in Practice, in: Carnegie-Rochester Conference Series on Public Policy, Vol. 39, pp. 195-2I4

Treasury (1997): Pre Budget Report, Cmnd. 3804, London: HMSO 